\title{
Industrial Semi-Solid Rheocasting of Aluminum A356 Brake Calipers
}

\author{
U. A. Curle, J. D. Wilkins, and G. Govender \\ Materials Science and Manufacturing, the Council for Scientific and Industrial Research, Meiring Naudé Road, \\ P. O. Box 395, Brummeria Pretoria 0001, South Africa
}

Correspondence should be addressed to U. A. Curle, ucurle@csir.co.za

Received 18 October 2010; Accepted 19 November 2010

Academic Editor: Shoujin Sun

Copyright (C) 2011 U. A. Curle et al. This is an open access article distributed under the Creative Commons Attribution License, which permits unrestricted use, distribution, and reproduction in any medium, provided the original work is properly cited.

Industrial semi-solid casting trials of aluminum A356 brake calipers were performed over five days with the CSIR-RCS and highpressure die casting process cell. Consecutive visual passed castings were used as the measure of process stability, and common defects between trials were categorized. Short fill results are erratic and caused by unintended underdosing by the furnace or incomplete billet discharge at the delivery point in the shot sleeve. Cold shuts can be significantly reduced by adjusting the shot control profile. Surface finish defects include surface roughness and staining caused by lubricant burn off. Visual passed castings display none of the above-mentioned external defects. X-ray examination and pressure testing of heat-treated castings from the consecutive visual passed castings show improvement over the five days. These initial-stage industrialization efforts pave the way for process commercialization.

\section{Introduction}

Since the concept of semi-solid metal forming was discovered in the early 1970s, the full potential of the process has not yet been realized. The initial hype about the benefits of forming near net shape high-integrity components resulted in a wide array of technological approaches being proposed [1]. Up to the early 2000s, the preferred approach was using the thixocasting method which requires reheating a billet with the desired globular microstructure to the semi-solid state and forming. The high cost of infrastructure and the actual processing of the material have limited the use of the process although this method has a great opportunity to produce high-quality components [2], especially in costsensitive markets like the automotive industry.

In order to make semi-solid metal (SSM) forming a viable option, the "slurry on demand" or rheocasting processes offer a more cost-effective method of preparing slurries for SSM forming. It was proposed [2] that the ideal process for SSM forming is a cell with an integrated slurry maker; the slurry maker needs to be efficient and capable of producing the desired microstructure and billet consistency with accurate process control. During the early 2000s, a myriad of rheocasting systems were developed, UBE (NRCNew Rheocasting), Honda (rheocasting), IDRA (SSR), THT presses, SOD (Slurry on demand), Mercury Marine, and New Rheo-Diecasting (Brunel University) to name a few [3]. Although rheocasting processes do provide a cost advantage over the thixocasting process, they have not been widely adopted by industry because the process is more expensive than conventional casting processes. Also, the consistency, efficiency, and repeatability of the processes need to be demonstrated with a high degree of confidence.

The Council for Scientific and Industrial Research in South Africa has developed and patented a rheocasting system (CSIR-RCS) [4, 5] in the early 2000s. Since then, testing was performed on a small-scale cell with different alloys including $\mathrm{Al}-7 \mathrm{Si}-\mathrm{Mg}$ [6] and $\mathrm{Al}-\mathrm{Cu}-\mathrm{Mg}-(\mathrm{Ag})$ [7] casting alloys; heat treatable $\mathrm{Al}-\mathrm{Cu}-\mathrm{Mg}, \mathrm{Al}-\mathrm{Mg}-\mathrm{Si}$, and $\mathrm{Al}-$ $\mathrm{Zn}-\mathrm{Mg}-\mathrm{Cu}$ wrought alloys [8], $\mathrm{SiC}_{\mathrm{p}}$ aluminum metal matrix composites [9] as well as high purity aluminum [10].

An industrial scale semi-solid metal high-pressure die casting cell with the CSIR-RCS unit at the heart was established in 2008/09. Although there was interest from 
potential industry partners, the key question continuously asked was: how stable and repeatable is the process? This paper will present the first phase of the work performed to demonstrate the industrial feasibility of the CSIRRCS through casting and industrial quality testing of aluminum A356 brake calipers in order to answer these questions.

\section{Experimental}

Aluminum A356 brake calipers were produced on five different days, each a single continuous run, with the CSIR-RCS and a high-pressure die casting (HPDC) machine. Figure 1 shows the brake caliper casting in drawing (including the runner and the biscuit) and the actual premachined component. The overall dimensions for the casting in Figure 1(a) is $327 \mathrm{~mm}$ high $\times 163 \mathrm{~mm}$ wide $\times 95 \mathrm{~mm}$ thick; the biscuit and gate diameters are $78 \mathrm{~mm}$ and $35 \mathrm{~mm}$, respectively.

Figure 2 gives the layout of the CSIR-RCS-HPDC cell. The main components that make up the cell are: a $240 \mathrm{~kg}$ dosing furnace (WESTOFEN WESTOMAT W25S), an automated robotic arm (FANUC ROBOT M-16iA), a three-coil version of the CSIR-RCS (induction stirring with simultaneous forced air cooling [4]) processing unit, and a 630 ton HPDC machine with full shot control (LK DCC630). The mechanical hardware operation of the cell runs automatically through computer control software (NATIONAL INSTRUMENTS LABVIEW 8.6).

The $240 \mathrm{~kg}$ dosing furnace was filled by melting commercial aluminum alloy A356 ingots in charges of approximately $40 \mathrm{~kg}$ each with a custom-made induction heating ladle furnace. The metal temperature in the dosing furnace was left to equilibrate after the last charge (with additional $\mathrm{Sr}$ ) was added. A sample was poured into a cup and chilled for chemical analysis by optical emission spectroscopy (Thermo Quantris OES). The composition of the aluminum alloy A356 melt was found to be $7.14 \mathrm{wt} \% \mathrm{Si}, 0.36 \mathrm{wt} \% \mathrm{Mg}$, 0.14 wt $\% \mathrm{Fe}, 0.13 \mathrm{wt} \% \mathrm{Ti}$, and $105 \mathrm{ppm} \mathrm{Sr}$ with the balance of Al.

Thermodynamic properties of the alloy were then calculated with an aluminum thermodynamic database (ProCast 2009.1) from the specific OES composition. Table 1 summarizes the calculated thermodynamic properties and deduced rheocasting parameters. A pouring temperature of approximately $40^{\circ} \mathrm{C}$ above the liquidus (the pouring temperature sensitivity has not yet been established) and a semisolid metal (SSM) processing temperature corresponding to a solid fraction of $26 \%$ are used from experience with this specific SSM processing cell system.

The sequence for casting was as follows: liquid metal was poured from the dosing furnace into a stainless steel processing cup (approximately $2 \mathrm{~kg}$ ) which was then robotically transferred to the CSIR-RCS unit and entered the coil train at the bottom. All three coils in the processing unit was inductive while forced air cooling was only used (manually activated) on the top coil to control the SSM temperature which was measured with a thermocouple in the semi-solid metal contained in the cup.

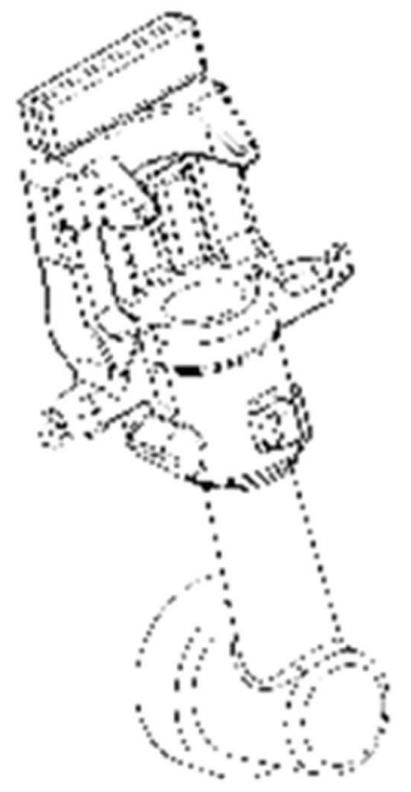

(a)

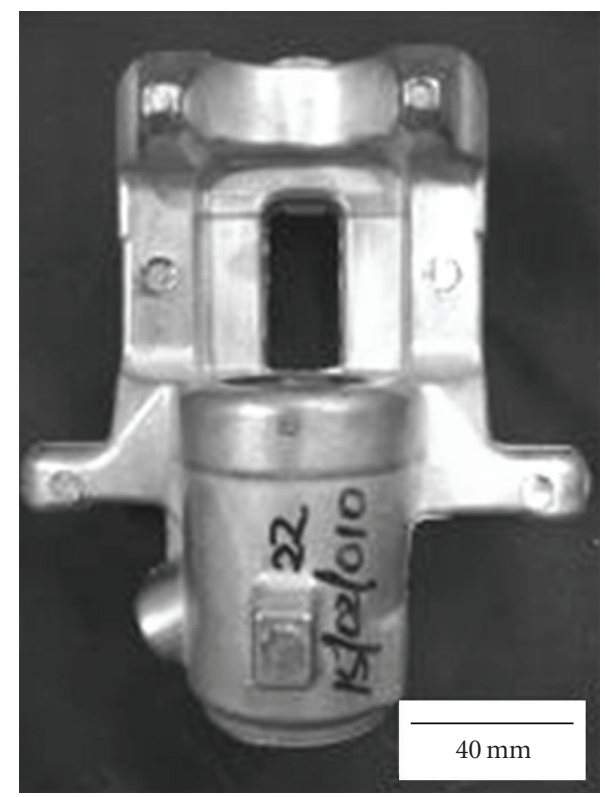

(b)

Figure 1: Example of the rheocast aluminum brake caliper including the runner and the biscuit in part drawing (a) and the actual premachined component (b).

When this cup at the top of the train thus been processed after reaching the SSM temperature, it was robotically transferred to the shot sleeve of the HPDC machine, and the injection shot was triggered automatically to fill the die. The die temperature was controlled by two oil heaters (REGLOPLAS $300 \mathrm{~L}$ ), one for each half of die, and was set at $170^{\circ} \mathrm{C}$.

The piston followed a set computer-controlled injection velocity profile which was adjusted at the beginning of each day to achieve the best filling result (within the first 4 


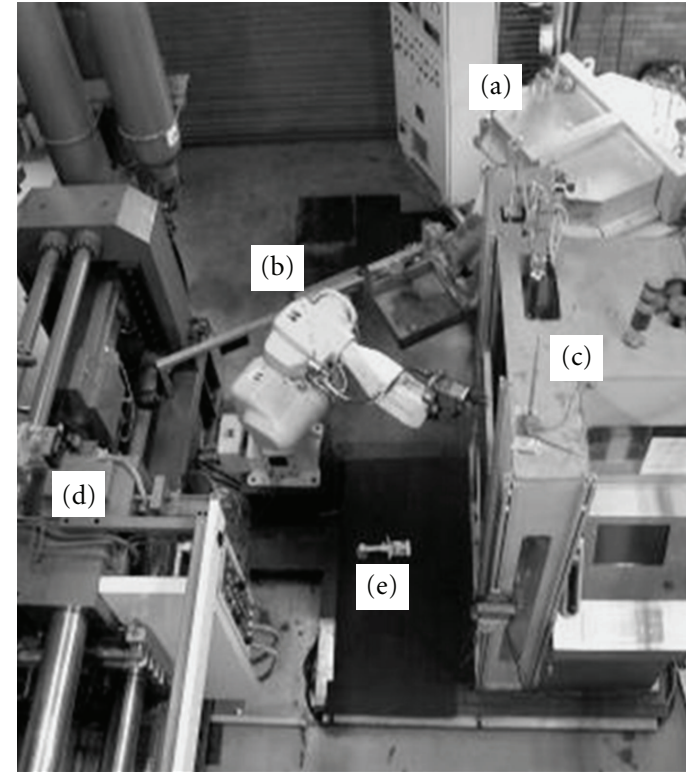

Figure 2: The CSIR-RCS-HPDC cell arrangement: automatic dosing furnace with controller (a), automated robotic arm (b), the CSIR-RCS processing unit (c), shot end of the 630 ton HPDC machine (d), and a brake caliper casting for scale (e).

castings) and was kept constant during the remainder of that day's particular run. These minor adjustments to the injection profile were to maintain repeatability. The casting was ejected after solidification and manually removed.

Each casting of a trial was visually examined for cold shuts, short fills, and surface finish. A visual pass was made on grounds of fulfilling the following three criteria: there were no externally visible cold shuts; the component filled properly which included the overflow and a proper biscuit thickness; lastly if the surface finish was macroscopically smooth.

Four visual pass castings were randomly selected from each day's trial. These twenty castings were solution heat treated at $540^{\circ} \mathrm{C}$ for 1 hour and quenched in water to accentuate porosity before independent X-ray examination. An X-ray examination pass was awarded after a standard combination of nine different positions was inspected in the casting and was found fit to continue to the machining section.

Two other castings were randomly selected from the visual passed castings and heat treated to peak strength (solution heat treated at $540^{\circ} \mathrm{C}$ for 1 hour and artificial ageing at $180^{\circ} \mathrm{C}$ for 4 hours [6]) for pressure leak rate tests after full machining. These final machined brake calipers were assembled into a pressure test system where leak rates are measured at both 2 bar and 140 bar.

\section{Results and Discussion}

Aluminum A356 brake caliper casting trials were successfully completed with a trial per day. A breakdown of casting trial results is given in Table 2. Castings produced per day ranged
TABLE 1: Calculated thermodynamic and deduced rheocasting parameters of A356 for the three-coil CSIR-RCS-HPDC cell.

\begin{tabular}{lcc}
\hline Parameter & Property & Temperature $/{ }^{\circ} \mathrm{C}$ \\
\hline \multirow{2}{*}{ Thermodynamic } & Liquidus & 610 \\
& Solidus & 548 \\
\multirow{2}{*}{ Rheocasting } & Pouring & 645 \\
& SSM & 590 \\
\hline
\end{tabular}

TABLE 2: Results of the aluminum A356 brake caliper casting runs on different days with the CSIR-RCS and HPDC.

\begin{tabular}{lccccc}
\hline Trial/day & A & B & C & D & E \\
\hline & \multicolumn{5}{c}{ /castings } \\
Castings produced & 23 & 18 & 31 & 25 & 31 \\
Consecutive visual pass & 5 & 8 & 12 & 13 & 13 \\
\hline \multicolumn{5}{c}{ Occurrence/\% } \\
Short fills & 0 & 27 & 3 & 24 & 16 \\
Cold shuts & 26 & 6 & 3 & 0 & 16 \\
Surface finish defects & 0 & 0 & 10 & 4 & 6 \\
\hline Total visual pass & 74 & 67 & 84 & 72 & 62 \\
\hline
\end{tabular}

between 18 and 31 castings. The aim was to produce between 25 and 30 castings per day so that comparisons are more meaningful.

The number of consecutive castings that passed the visual test, in any particular trial, was taken as the measure of improvement and an indication of process repeatability. Table 2 shows that there was indeed an improvement over the five days where the last trial produced nearly three times as many consecutive castings that passed the visual examination compared to the first trial. The total visual pass rate as a measure of repeatability is subjective because it is not related to chronological castings in the process.

Common defect classes were identified for reject castings and are shown in Table 2. Short fill defects are related to irregular billet mass delivery to the shot sleeve and cold shut defects are related to the injection piston velocity profile. Surface finish defects with this specific die are related to lubricant, applied intermittently to the sliding core, spilling into the die cavity. The total number of castings that passed the visual evaluation completes the balance.

There is no real trend evident from the short fill rate results, Table 2, between the different days; the cause is intermittent. Short fills such as those in Figure 3 are normally associated with too little material entering the die. In the current casting cell system, this can happen, although not distinguished between in the Table 2 , either by an unintended gross underdosing mass from the dosing furnace or by billet material remaining in the cup after billet delivery to the shot sleeve.

Figure 4 shows typical cold shuts which are associated with inadequate joining of the separate metal flow fronts during filling. The rate of cold shuts in Table 2 started off at $26 \%$ in Trial A and decreased to $0 \%$ by Trial D, this was achieved by manually adjusting the injection piston velocity profile mainly for the minor change in day-to-day mass 


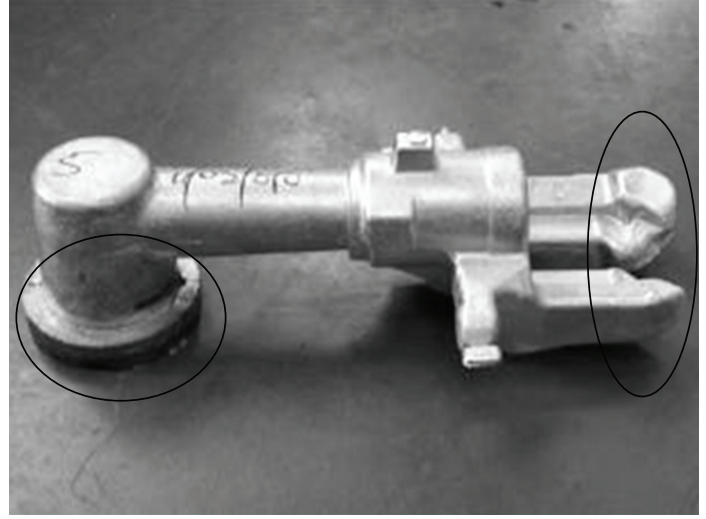

Figure 3: An example of a short fill defect brake caliper casting produced during trials with the CSIR-RCS-HPDC cell indicating a thin biscuit in conjunction with an incomplete casting.

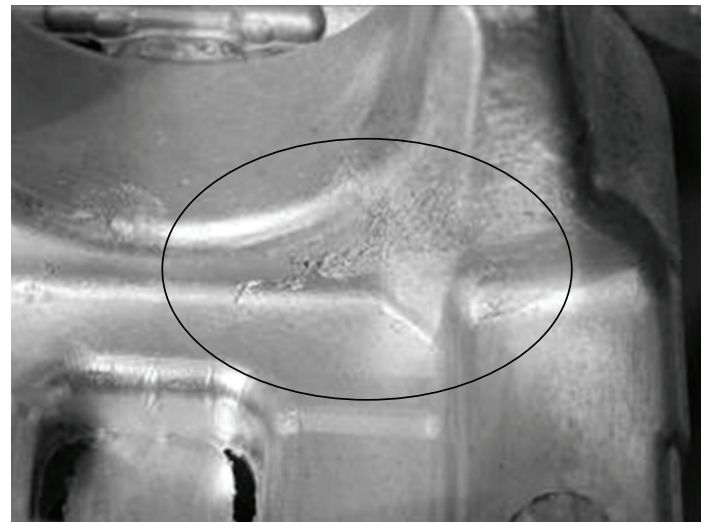

FIgURE 4: An example of a cold shut defect brake caliper casting produced during trials with the CSIR-RCS-HPDC cell.

of the billet delivered into the shot sleeve. The cold shut rate increased on the last day because a position value in the velocity profile was initially adjusted towards the wrong direction which exacerbated this defect rate.

Surface finish defects manifest by increased surface roughness due to volatilization of the oily compounds and staining by resulting soot as shown in Figure 5. Surface finish defect rates in Table 2 seem to have suddenly increased from $0 \%$ during Trial A and Trial B to in the order of $10 \%$ during subsequent trials. This kind of defects goes unnoticed when gross defects like short fills and cold shuts persist.

Visual passed castings in Table 2 all underwent a critical external examination. All these castings properly filled the die cavity into the overflows, and no external cold shuts were perceptible. All castings surfaces were examined and passed if found to be smooth with a bright luster. Figure 6 shows a casting that passed all the visual examinations.

Industrial quality pass rate results of X-ray and pressure tests are given in Table 3 for consecutive visual passed castings produced as the measure of quality that underscribes the stability and repeatability of the CSIR-RCS-HPDC process cell. Other castings were also X-rayed and pressure tested but

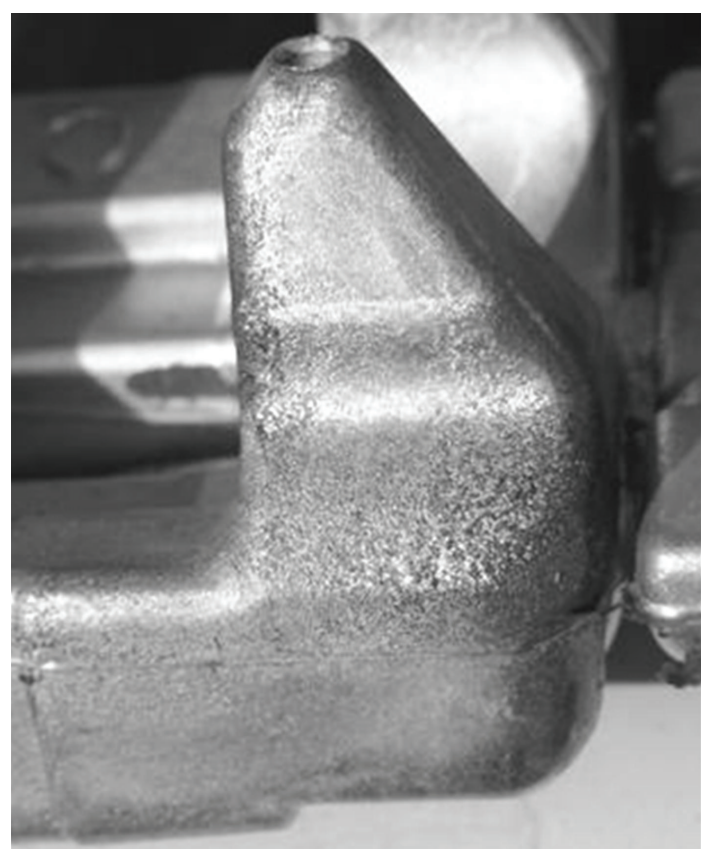

Figure 5: An example of the rough surface finish of a lubricant defect brake caliper casting produced during trials with the CSIRRCS-HPDC cell.

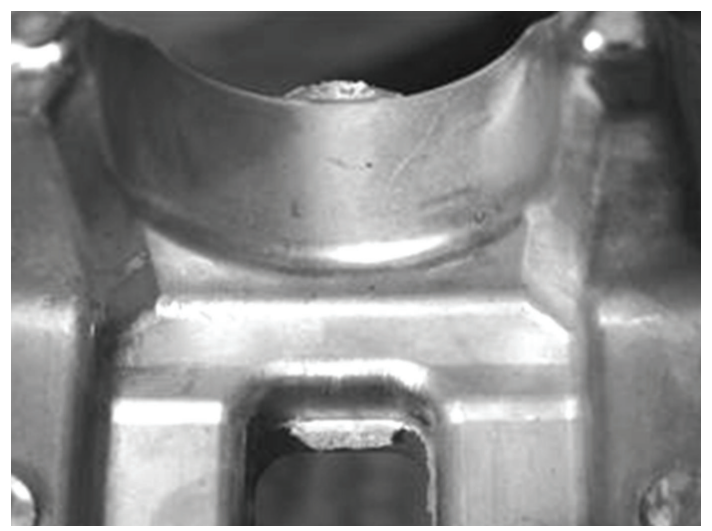

Figure 6: An example of a visually inspected and passed brake caliper casting produced during trials with the CSIR-RCS-HPDC cell without any external defects.

bears no meaningful relation to the stability of the process following the argument on the number of consecutive visual passed castings. The total number of castings tested differs between days because the samples for X-ray and pressure tests were initially random chosen from the total visual passed castings and afterwards again combined with the consecutive visually passed casting results.

$\mathrm{X}$-ray tests were done at a local manufacturer that currently makes this brake caliper by another casting process which is set up to do extensive automated positioning evaluations in-house. The question of pass or fail was posed to the manufacturer by deciding if the casting would pass for subsequent machining as if it was one of their own castings, without explanations. This approach was followed to ensure 
TABLE 3: X-ray and pressure test quality control sample of consecutive visually passed castings achieved on the different days with the CSIR-RCS and HPDC. X-rayed brake calipers were solution heattreated at $540^{\circ} \mathrm{C}$ for 1 hour and quenched. Pressure tested brake calipers were peak aged by solution heat treatment at $540^{\circ} \mathrm{C}$ for 1 hour, quenched and artificially aged at $180^{\circ} \mathrm{C}$ for 4 hours.

\begin{tabular}{lccccc}
\hline Trial/day & A & B & $\begin{array}{c}\text { C } \\
\text { /castings }\end{array}$ & D & E \\
\hline X-rayed test & 2 & 2 & 2 & 3 & 3 \\
Pressure test & & & & & 1 \\
Total tested & 2 & 2 & 2 & 3 & 4 \\
\hline Pass X-ray test & 1 & 1 & 2 & 2 & 3 \\
Pass pressure test & & & & & 1 \\
Total passed & 1 & 1 & 2 & 2 & 4 \\
\hline Sample pass rate/\% & 50 & 50 & 100 & 67 & 100 \\
\hline
\end{tabular}

TABLE 4: Stability and quality summery table for brake caliper casting trials over five days with the CSIR-RCS-HPDC process cell.

\begin{tabular}{lccccc}
\hline Trial/day & A & B & C & D & E \\
\hline $\begin{array}{l}\text { Consecutive visually } \\
\text { passed/castings }\end{array}$ & 5 & 8 & 12 & 13 & 13 \\
Quality pass rate/\% & 50 & 50 & 100 & 67 & 100 \\
\hline
\end{tabular}

a higher degree of impartiality. Again it is clear from the sample pass rate in Table 3 that improvement was made over time.

Table 4 gives the summery of the success achieved with the CSIR-RCS-HPDC process cell in these early stages of industrial trials with this rheocasting process en-route to commercialization efforts. Extensive heat treatment optimization and tensile property testing have been addressed for these aluminum A356 brake calipers which show the tensile properties to be $261 \mathrm{MPa}$ yield strength, $317 \mathrm{MPa}$ ultimate tensile strength, and $6.7 \%$ elongation [11].

\section{Conclusions}

Industrial semi-solid casting trials of aluminum A356 brake calipers were successfully completed on five different days with a CSIR-RCS-HPDC process cell where consecutive visually passed castings was used as a measure of process stability because of a chronological time relationship. Common defects between trials were categorized. Short fills, which are erratic and caused by underdosing of metal into the cup or incomplete discharge at the delivery point in the shot sleeve resulting in incomplete filling of the die cavity. Cold shuts are metal flow-related problems, and their occurrence can significantly be reduced by adjusting the injection piston velocity profile during the start of a trial. Surface finish defects are related to the mechanics of this specific die and can be solved with a better die design. None of the defects are rheoprocessing related but are ancillary equipment related.

Visually passed castings display none of these classified external defects while X-ray examination and pressure testing of heat-treated castings from consecutive visual passed castings show improvement over the five day trial ending in a $100 \%$ quality sample pass rate.

These early successful efforts of industrial trials pave the way for commercialization of the CSIR-RCS.

\section{References}

[1] D. B. Spencer, R. Mehrabian, and M. C. Flemings, "Rheological behavior of $\mathrm{Sn}-15 \mathrm{pct} \mathrm{Pb}$ in the crystallization range," Metallurgical Transactions, vol. 3, no. 7, pp. 1925-1932, 1972.

[2] Z. Fan, "Semisolid metal processing," International Materials Reviews, vol. 47, no. 2, pp. 49-86, 2002.

[3] P. Kapranos, "Semi-solid metal processing-a process looking for a market," Diffusion and Defect Data Part B, vol. 141-143, pp. 1-8, 2008.

[4] R. Bruwer, J. D. Wilkins, L. H. Ivanchev, P. Rossouw, and O. F. R. A. Damm, "Method of and apparatus for processing of semi-solid metal alloys," US7368690, 2008.

[5] L. Ivanchev, D. Wilkins, and G. Govender, "Method and apparatus for rheo-processing of semi-solid metal alloys," in Proceedings of the 8th International Conference on Semi-Solid Processing of Alloys and Composites (S2P '04), pp. 595-601, Limassol, Cyprus, 2004, Paper 15-2.

[6] H. Möller, G. Govender, W. E. Stumpf, and P. C. Pistorius, "Comparison of heat treatment response of semisolid metal processed alloys A356 and F357," International Journal of Cast Metals Research, vol. 23, no. 1, pp. 37-43, 2010.

[7] E. P. Masuku, H. Möller, R. Knutsen, L. Ivanchev, and G. Govender, "Optimisation of the solution heat treatment of rheo-processed Al-Cu-Mg-(Ag) alloys A206 and A201," Materials Science Forum, vol. 618, pp. 353-356, 2009.

[8] U. A. Curle, "Semi-solid near-net shape rheocasting of heat treatable wrought aluminum alloys," Transactions of Nonferrous Metals Society of China (English Edition), vol. 20, no. 9, pp. 1719-1724, 2010.

[9] U. A. Curle and L. Ivanchev, "Wear of semi-solid rheocast $\mathrm{SiC}_{\mathrm{p}} / \mathrm{Al}$ metal matrix composites," Transactions of Nonferrous Metals Society of China (English Edition), vol. 20, supplement 3, pp. s852-s856, 2010.

[10] U. A. Curle, H. Mölle, and J. D. Wilkins, "Shape rheo-casting of high-purity aluminium,” Scripta Materialia. In press.

[11] H. Möller, G. Govender, and W. E. Stumpf, "Application of shortened heat treatment cycles on A356 automotive brake calipers with respective globular and dendritic microstructures," Transactions of Nonferrous Metals Society of China (English Edition), vol. 20, no. 9, pp. 1780-1785, 2010. 

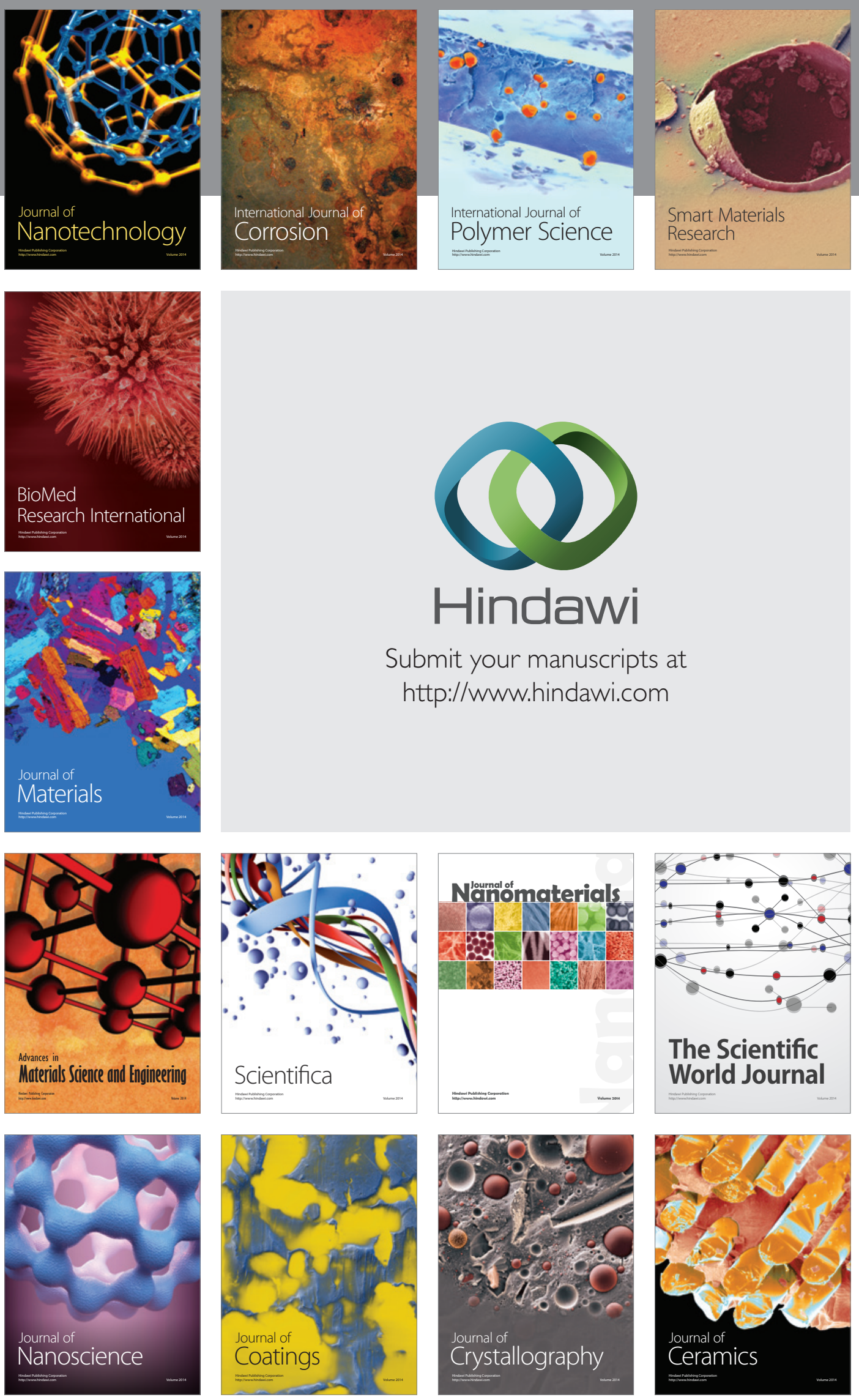

The Scientific World Journal

Submit your manuscripts at

http://www.hindawi.com

\section{World Journal}

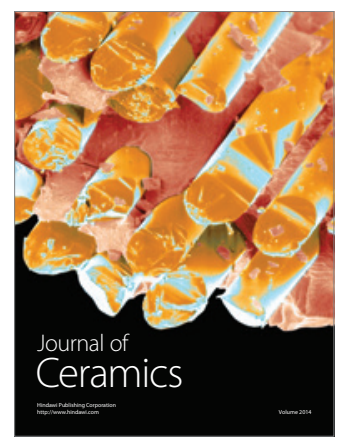

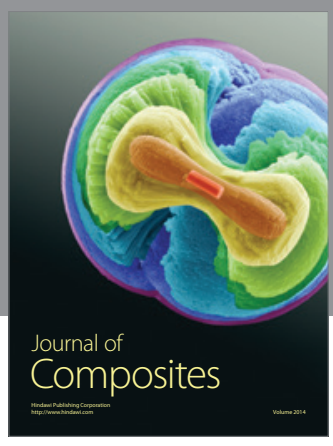
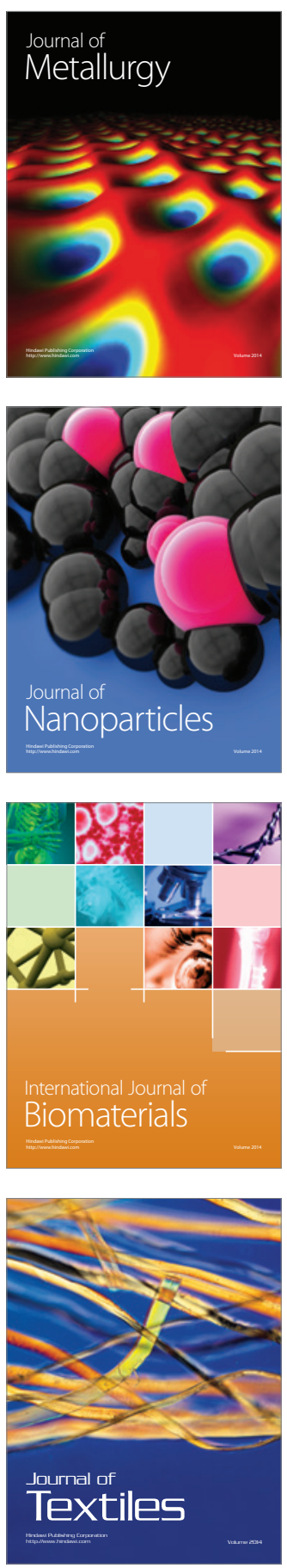